\title{
Analysis of English Learning Material Computer Engineering Department for Universitas Negeri Padang Students Based on Their Needs
}

\author{
Rahma Widi $^{*}{ }^{*}$ Refnaldi ${ }^{1}$ \\ ${ }^{1}$ English Department, FBS Universitas Negeri Padang, Padang, Sumatra Barat 25131, Indonesia \\ *Corresponding author. Email: rahmahwidirw@gmail.com; refnaldi@yahoo.com
}

\begin{abstract}
English learning material is one of resource in the teaching and learning process. Commonly, the students need appropriate learning material during learning English, especially for computer engineering department students. They need specific material to fulfil their needs in the learning process. From explanation above, this study aimed to find out the English learning material computer engineering department for Universitas Negeri Padang students based on their needs. Furthermore, the subjects of this study were Computer Engineering Department students at Universitas Negeri Padang. This study was an evaluation research to evaluate and describe the English learning material based on students' needs. This study was conducted by evaluative checklist. The evaluators evaluated the English learning material computer engineering department based on students' need. As a result of the study, the evaluation was identified and classified based on several indicators. It consists of language content, topic, skills, and task or activity.
\end{abstract}

\section{Keywords: Evaluation English Learning Material, Students’ Need}

\section{INTRODUCTION}

In education, the use of English to learn subject area knowledge is increased, especially English for specific purposes, such as English for business, English for technology, English for medical, etc. Thus, teaching English is major priority in the education field, especially at university level. Many educational institutions offer the program of ESP courses to meet student's future career need in the global trend. This is in accordance with the Government policy on Education that emphasizes the goal of teaching English at higher school level requires to improve the students' ability to use English for academic and professional purposes. It is proven that the aim of ESP courses is to equip the learners with a certain English proficiency level for a situation where the language is going to be used, particularly in the workplace [1]. So that it is important to give what students need in learning English.

In line with explanation above, ESP should meet the learners' specific need and should make the learners' learn something based on their reason for learning by conducting a need analysis. The purpose of need analysis is to figure out the needs of the learners in terms of language use in the target situation and the need of the learners to acquire the language learned. The theoretical findings would be of benefit to the teacher in achieving English teaching objectives. This can encourage the learners to be good in English and once they graduate it will help to introduce the English.

In one case, the materials provided at university level in the English subject, especially in the nonEnglish study program, are irrelevant to the context and need of the students. This happen for some reasons, such as lack of material specified for certain purposes and lack of learning motivation for the students. It is proven that the activity that is interesting for the teachers is taking the students to analyse, synthesize and summarize the materials [2]. In other words, the teacher does not consider the material based on the students' need. Therefore, selecting the appropriate materials that suit the needs of students can help them understand the languages they in their fields.

In computer engineering majors, they often use terms in English. If the English material provided is not in accordance with what should be their needs, these students will experience difficulties when they enter the world of work. Therefore, it is necessary to evaluate the English language material to assess whether the material provided is in accordance with their needs. Thus, evaluation can be used as a method and can be considered to be one of the means used to assess and compare objects in their various ways [3].

Moreover, there are several studies have been conducted about the evaluation of the material for ESP students. to find out whether the material is relevant to 
students need or not. They found that the materials were not fully relevant to the learning needs and it was not suitable for the course [4] [5] [6]. Among those several previous studies, the evaluation of English learning material also caught the attention of many researchers in some countries, it is divided into some majors, such as Saudia Arabia [7]; Iran [8] [9]; Malaysia [10]; and Mexico [11]. Some of these studies found that the English material given to the ESP students were not appropriate according to the students' need [7][8][9]. In contrast, there are studies found that the ESP material was designed based on the needs analysis of the learners and can be used as an acceptable material to teach the ESP students [10][11].

While in Indonesia, there are several studies conducted the evaluation of English learning material that focusing for the engineer students at university level. From their research, it is found that the book has low face validity and contains inappropriate drills. In additions the material for teaching English should include the four languages skills component, such as listening, reading, speaking, and writing and the two language contents like grammar and the knowledge of vocabularies [12][13][14].

The students of Computer engineering at Universitas Negreri Padang got the Bahasa Inggris Teknik subject in the fourth semester. Based on the result of the interview, some students said that they still have lack vocabulary. In fact, they often use terms in English so they got problem in understanding the words. Some of the students revealed that they still have a problem in speaking skill. They said that speaking is a necessary skill that they must have.

Therefore, this research evaluated the English learning material based on the students' need to find out whether the material meet the good criteria on English learning material for ESP students. The items of language content, topic, skill, and activity were asked to the students to find out the needs of the students in learning English for computer engineering. The criteria to evaluate the material are based on the result of need analysis of students' need. Post-use type of evaluation were used in this research since it was conducted after the participants have has reasonable time using the materials.

\section{METHODS}

The type of this research is evaluation research, since it focuses on making decision and judgement about the quality, effectiveness, merit, or value of education program, product or practice. The evaluation research was conducted on English learning material of computer engineering students at Universitas Negeri Padang. The material is in form of handouts that consists of 14 chapters. The material evaluated by using the results of students' need analysis as the criteria. This research has evaluator who filled out the evaluation checklist to evaluate the material. Evaluation checklist is one the standard methods for assessing English language Teaching material. It provides researchers with a list of criteria for good learning-teaching resources [15].

\section{RESULT AND DISCUSSION}

The criteria that is used to evaluate the English learning material is gotten from the result of need analysis of the students. The result of need analysis is gotten from the questionnaire and interview. The criteria are in the terms of language content, topic, skills, and activity. The language content contains vocabulary that consists of 7 topics; and grammar structure contains 9 topics. For topic, it has 12 topic materials. For skills, speaking has 9 topics, listening has 4 topics, reading has 4 topics, and writing has 9 topics. For the activity, it has 9 activities.

The score of evaluative checklist was analysed by counting the average score of every item by using the formula suggested [16]. The format of likert scale are instructed and the weight commonly in scale 0 to 4 for each categories.

$$
\prod=\frac{\varepsilon \chi}{\mathbf{t}}
$$

Where:

$\Pi$ : Mean score

$\varepsilon \chi:$ The total of grades grade

tt : Number of grades

After that, the researcher converted the result based on the table below:

Table 1. The Conversion of Average Score Into Description

\begin{tabular}{|l|l|l|}
\hline $\begin{array}{c}\text { Average } \\
\text { Score }\end{array}$ & \multicolumn{1}{|c|}{ Percentage } & \multicolumn{1}{|c|}{ Description } \\
\hline $3.51-4.00$ & $91-100$ & Very suitable \\
\hline $2.51-3.50$ & $51-90$ & Suitable \\
\hline $1.51-2.50$ & $11-50$ & Less suitable \\
\hline $1.00-1.50$ & $0-10$ & Not suitable \\
\hline
\end{tabular}

\subsection{Language Content}

3.1.1 Vocabulary

Table 2. The Result of Checklist Evaluation for Vocabulary

\begin{tabular}{|l|l|}
\hline The Material of Vocabulary & Score \\
\hline Vocabulary related to jobs & 3 \\
\hline Vocabulary related to computers & 4 \\
\hline Vocabulary related to websites & 4 \\
\hline Vocabulary related to database & 4 \\
\hline Vocabulary related to networking & 4 \\
\hline
\end{tabular}




\begin{tabular}{|l|l|}
\hline Vocabulary related to reporting & 4 \\
\hline $\begin{array}{l}\text { Form the sentences by using the } \\
\text { vocabulary taught }\end{array}$ & 3 \\
\hline Mean Score & $\mathbf{3 , 7 1}$ \\
\hline
\end{tabular}

The result of the evaluation shows that the mean score of the vocabulary material is 3.71 . The vocabulary related to jobs material got the score 3 because the material in the handouts given did not explain the vocabulary related to jobs fully. For the last indicator that got score 3 , only in one chapter that ask the students to form the sentence. From the result of the mean score, the vocabulary material achieves the average score 3.71, it is qualified as very suitable. It means that the degree of fitness of the materials is $91-100 \%$. Thus, most of the materials of the handouts used match to the indicators.

\subsubsection{Grammar Structure}

Table 3. The Result of Checklist Evaluation for Grammar Structure

\begin{tabular}{|l|l|}
\hline The Material of Grammar Structure & Score \\
\hline Tenses & 4 \\
\hline Schedules & 0 \\
\hline Question Words $(5 \mathrm{~W}+1 \mathrm{H})$ & 4 \\
\hline Linking Ideas & 0 \\
\hline Parts of Speech & 4 \\
\hline Article (a, an, the) & 0 \\
\hline Quantifiers & 0 \\
\hline Gerund & 3 \\
\hline Degree of Comparison & 4 \\
\hline Mean Score & $\mathbf{2 . 1}$ \\
\hline
\end{tabular}

Table 3 shows that the mean score of grammar structure is 2.1. The indicator that got 0 score because there is no that material in the material used. From the result of the mean score, the grammar stucture material achieves the average score 2.1 , it is qualified as less suitable. It means that the degree of fitness of the materials is $11-50 \%$. Thus, most of material used do not match to the indicators.

\subsection{Topic}

Table 4. The Result of Checklist Evaluation for Topic

\begin{tabular}{|l|l|}
\hline The Material of Topic & Score \\
\hline Programming and Languages & 4 \\
\hline Internet & 4 \\
\hline $\begin{array}{l}\text { Computers Engineering for Technician } \\
\text { (field worker, computer hardware) }\end{array}$ & 4 \\
\hline Graphic and Multimedia & 4 \\
\hline $\begin{array}{l}\text { Computer Engineering for Programming } \\
\text { (Computer Software) }\end{array}$ & 4 \\
\hline $\begin{array}{l}\text { Computer Viruses and Computer } \\
\text { Security }\end{array}$ & 4 \\
\hline
\end{tabular}

\begin{tabular}{|l|l|}
\hline $\begin{array}{l}\text { Presenting in English for Computer } \\
\text { Engineering }\end{array}$ & 0 \\
\hline Operating Systems & 4 \\
\hline Computers in Education & 1 \\
\hline Careers in Computing & 3 \\
\hline $\begin{array}{l}\text { Introduction to English for Computer } \\
\text { Material }\end{array}$ & 4 \\
\hline Computer Engineering for Social Life & 0 \\
\hline Mean Score & $\mathbf{3}$ \\
\hline
\end{tabular}

The result of the evaluation shows that the mean score of the topic is 3 . There are two materials are not used in the handouts used, such as presenting in English for computer engineering and computer engineering for social life. Computer in education got score 1 since the material used only present in one chapter. From the result of the mean score, the topic material achieves the average score 3 . It is qualified as suitable the degree of fitness of materials is $51-90 \%$. Thus, most of the materials of the handouts match to the indicators.

\subsection{Skills}

\subsubsection{Speaking}

Table 4. The Result of Checklist Evaluation for Speaking

\begin{tabular}{|l|l|}
\hline The Material of Speaking & Score \\
\hline $\begin{array}{l}\text { Asking for, giving and receiving } \\
\text { specific information }\end{array}$ & - \\
\hline Presenting a designed product & - \\
\hline $\begin{array}{l}\text { Preparing a poster and interpreting } \\
\text { visual material }\end{array}$ & - \\
\hline $\begin{array}{l}\text { Taking part in discussion and } \\
\text { negotiations }\end{array}$ & - \\
\hline Participating in an interview & - \\
\hline Greeting and self-introducing & - \\
\hline Describing job & - \\
\hline Describing computer software & - \\
\hline $\begin{array}{l}\text { Asking and giving information about } \\
\text { solving customer service and problems }\end{array}$ & - \\
\hline Mean Score & - \\
\hline
\end{tabular}

\subsubsection{Listening}

Table 5. The Result of Checklist Evaluation for Listening

\begin{tabular}{|l|l|}
\hline The Material of Listening & Score \\
\hline Listening test filling the missing gap & - \\
\hline Note taking & - \\
\hline $\begin{array}{l}\text { Listening to the information about } \\
\text { solving customer service and problem }\end{array}$ & - \\
\hline $\begin{array}{l}\text { Listening to greeting and self- } \\
\text { introduction }\end{array}$ & - \\
\hline Mean Score & - \\
\hline
\end{tabular}


The students did not get the speaking and listening material. The handouts used do not consist the speaking and listening material. From the result of need analysis, the Computer engineering students need speaking and listening skill materials.

\subsubsection{Reading}

Table 6. The Result of Checklist Evaluation for Reading

\begin{tabular}{|l|l|}
\hline The Material of Reading & Score \\
\hline $\begin{array}{l}\text { Skimming for the gist of a piece of } \\
\text { writing }\end{array}$ & 4 \\
\hline Scanning for specific information & 4 \\
\hline $\begin{array}{l}\text { Understanding text structure (its } \\
\text { organization and cohesion) }\end{array}$ & 4 \\
\hline $\begin{array}{l}\text { Inferring meaning and the intention of } \\
\text { the author(s) }\end{array}$ & 4 \\
\hline Mean Score & $\mathbf{4}$ \\
\hline
\end{tabular}

The table 6 shows that the mean score is 4 . It is classified as very suitable. It means the degree of fitness of materials is $91-100 \%$. Thus, most of the materials of the handouts used match to the indicators.

\subsubsection{Writing}

Table 7. The Result of Checklist Evaluation for Writing

\begin{tabular}{|l|l|}
\hline The Material of Writing & Score \\
\hline $\begin{array}{l}\text { Describing a device and making a guide for } \\
\text { its usage }\end{array}$ & 4 \\
\hline Preparing a report about an operating system & 4 \\
\hline Writing a memo, business letter, fax, etc. & 2 \\
\hline $\begin{array}{l}\text { Designing an advertisement for computer } \\
\text { software product }\end{array}$ & 0 \\
\hline $\begin{array}{l}\text { Reply to the email about introduce yourself } \\
\text { and people in the group }\end{array}$ & 0 \\
\hline Write a job description & 4 \\
\hline Write an email about comparing product & 3 \\
\hline Write sentence about comparing software & 3 \\
\hline Arrange sentences into good paragraph & 4 \\
\hline Mean Score & $\mathbf{3}$ \\
\hline
\end{tabular}

The result of the evaluation shows that the mean score of the topic is 3. There are two materials are not used in the handouts used, such as designing an advertisement for computer software product and reply to the email about introduce yourself and people in the group. From the result of the mean score, the writing material achieves the average score 3 . It is qualified as suitable the degree of fitness of materials is $51-90 \%$. Thus, most of the materials of the handouts match to the indicators.

\subsection{Activity}

Table 8. The Result of Checklist Evaluation for Activity

\begin{tabular}{|l|l|}
\hline The Material of Activity & Score \\
\hline $\begin{array}{l}\text { Introducing yourself and others. (Bagaimana } \\
\text { anda menyapa orang di negaramu? Apa yang } \\
\text { anda ucapkan saat anda menyapa orang-orang } \\
\text { dalam Bahasa Inggris?) }\end{array}$ & 4 \\
\hline $\begin{array}{l}\text { Describing your job. (Menjelakan pekerjaan } \\
\text { impianmu di depan kelas) }\end{array}$ & 0 \\
\hline $\begin{array}{l}\text { Describing your daily routine and times. } \\
\text { (Menjelakan kegiatan sehari-harimu, kapan } \\
\text { dimulai dan selesai) }\end{array}$ & 0 \\
\hline $\begin{array}{l}\text { Using the alphabet. (Buatkan singkatan- } \\
\text { singkatan yang anda tahu) }\end{array}$ & 0 \\
\hline $\begin{array}{l}\text { Describing computer hardware. (Buat daftar } \\
\text { semua perangkat keras komputer yang Anda } \\
\text { gunakan dalam bekerja atau belajar) }\end{array}$ & 4 \\
\hline $\begin{array}{l}\text { Describing computer software. (Buat daftar } \\
\text { semua perangkat lunak komputer yang Anda } \\
\text { gunakan dalam bekerja atau belajar) }\end{array}$ & 4 \\
\hline $\begin{array}{l}\text { Describing tasks. (Dengarkan dan lengkapi } \\
\text { percakapan) }\end{array}$ & 2 \\
\hline $\begin{array}{l}\text { Understanding computer usage. (Buat daftar } \\
\text { penggunaan computer tempat anda bekerja } \\
\text { atau belajar) }\end{array}$ & 4 \\
\hline $\begin{array}{l}\text { Booking e-ticket. (Menjelaskan bagaimana } \\
\text { memesan e-tiket) }\end{array}$ & 4 \\
\hline $\begin{array}{l}\text { Explaining terms of computer virus. } \\
\text { (Menjelaskan istilah-istilah virus computer) }\end{array}$ & 4 \\
\hline Mean Score & $\mathbf{2 . 6}$ \\
\hline
\end{tabular}

The result of the evaluation shows that the mean score of the topic is 2.6. There are three materials are not used in the handouts used. Describing task got score 2 since the material used only present in one chapter but the instruction is quite clear. From the result of the mean score, the topic material achieves the average score 2.6. It is qualified as suitable the degree of fitness of materials is $51-90 \%$. Thus, most of the materials of the handouts match to the indicators.

\section{CONCLUSION}

In this research, there are four indicators that are used to evaluate the English learning material. The indicators are language content (vocabulary and grammar structure), topic; skills (speaking, listening, reading, and writing); and activity. The English learning material that is evaluated in this research is in the form of handouts.

Each indicators show different results. It can be seen from the indicators Language Content which consists of vocabulary and grammar. Vocabulary material is 
classified as very suitable whereas grammar structure is classified as less suitable. For topic indicator, it is found that most of the material of the handouts used match to the indicators since it is classified as suitable. Besides, for Skills indicators that consists of speaking, listening, reading, and writing have different results. Speaking and listening material are not present in the handouts used. Thus, the indicators of speaking and listening cannot be used. But, from the result of need analysis, it is proven that the computer engineering students at UNP need speaking and listening material. Meanwhile, reading material is classified as very suitable and writing is classified as suitable. The last indicator is Activity. The activity of the computer engineering students is classified as suitable. Thus, most of the activity of the handouts match to the indicators.

To be concluded, from the result of the average score, the English learning material of Computer engineering students at Universitas Negeri Padang is classified as less suitable. The average score of the English learning material used is 2.3. Since the material achieves the average score $1.51-2.50$, it is qualified as less suitable. It means that the degree of fitness of materials is $11-50 \%$.

\section{AUTHORS' CONTRIBUTIONS}

It is hoped that the description in this research can be used as a reflection for other researchers. The other researcher can evaluate in other aspects. It is also essential to assist in developing the English learning material especially for Computer Engineering students at university level.

\section{ACKNOWLEDGMENTS}

A great appreciation for the lecturers who give a contribution in finishing this study, especially the lecturers at Universitas Negeri Padang. I also would like to thank to my advisor Dr. Refnaldi, M.Litt. who help and guide me in doing this study.

\section{REFERENCES}

[1] Kusni, A (2013). Reformulating English for Specific Purposes (ESP) in Indonesia: Current issues and future prospects. Proceedings of National Seminar on English Language Teaching (pp.36-48), UniversitasNegeri Padang, Padang 2013

[2] Azza, B. (2013). ESP Materials Selection The case of Second Year Computer Science Students at Ouargla University (Doctoral dissertation).

[3] Kashoob, M. (2018). Evaluating ELT Materials with Specific Reference to Colleges of Applied Sciences General Foundation Programme in
Oman: Towards a Viable checklist (Doctoral dissertation, University of York).

[4] Baleghizadeh, S., \& Rahimi, A. H. (2011) Evaluation of an ESP Textbook for the Students of Sociology. Journal of Language Teaching \& Research, 2(5).

[5] EL-Sakran, T. M. \& Awad, A. (2012). Voices from the United Arab Emirates: Engineering graduates' labour market requisite competencies. American Journal of Engineering Education, Vol. 3, No. 2, pp. 105-114.

[6] Suyuti, L., Manda, M. L., \& Bazergan, E. (2013). Evaluasi Materi Bahasa Inggris Bertujuan Tertentu Pada Politeknik Negeri Ujung Pandang (Doctoral dissertation, Tesis, Fakultas Ilmu Budaya: Universitas Hasanuddin Makassar).

[7] Liton, A. (2012). Developing EFL Teaching And Learning Practices In Saudi Colleges: A Review. International Journal of Instruction, 5(2), 129-152. https://eric.ed.gov/?id=ED533782

[8] Danaye Tous, M., \& Haghighi, S. (2014). Evaluation of ESP textbooks: Evidence from ESP textbook of computer engineering major. International Journal of Research Studies in Language Learning, 3(2), 55-68

[9] Karimnia, A., \& Jafari, F. M. (2017). Critical ESP textbook evaluation: The case of visual arts textbook. Sustainable Multilingualism, 11(1), 219236. https://doi.org/10.1515/sm-2017-0020.

[10] Salehi, H., Khadivar, Z., Babaee, R., \& Singh, H. K. A. J. (2015). An Evaluating Study on ESP Medical Textbook: Instructors and Learners' Needs Analysis. English Language Teaching, 8(8), 142151.

[11] Najafi Sarem, S., Hamidi, H., \& Mahmoudie, R. (2013). A critical look at textbook evaluation: A case study of evaluating an ESP course-book: English for international tourism. International Research Journal of Applied and Basic Sciences, 4(2), 372-380.

[12] Firharmawan, H. (2016). A Critical Evaluation of English for Informatics ESP Textbook At Department of Informatics and Technology of University of Ma'arif Nahdlatul Ulama (UMNU) Kebumen. ETERNAL (English Teaching Journal), $7(1)$.

[13] Astuti, I. (2018). An Evaluation of English Learning Materials for Information and Technology Students Department at Politeknik Negeri Padang. International Journal of Educational Dynamics, 1(1), 18-29.

[14] Aniqoh, A. N. I. K. (2018). Need Analysis Of Esp Materials For The Medical Laboratory Technology Students In The Health Polytechnics Semarang 
(Doctoral dissertation, Thesis: Muhammadiyah University Of Surakarta).

[15] Danaye Tous, M., \& Haghighi, S. (2014). Evaluation of ESP textbooks: Evidence from ESP textbook of computer engineering major. International Journal of Research Studies in Language Learning, 3(2), 55-68

[16] Sudjana, N. (2005). Metode statistika. Bandung: Tarsito, 168. 